\begin{tabular}{l|ll} 
J B E & $\mid \begin{array}{ll}\text { JOURNAL OF } \\
\text { BIOLOGY }\end{array}$ & $\begin{array}{l}\text { E-ISSN 2656-3436/ P-ISSN 2615-3947 } \\
\text { IAIN KUDUS } \\
\text { Tersedia online: http://journal.iainkudus.ac.id/index.php/jbe }\end{array}$ \\
\hline
\end{tabular}

\title{
The Relationship Between Student's Creativity and Cognitive Learning Outcome Through the Implementation of Project Based Learning on Biology
}

\author{
Iseu Laelasari ${ }^{1}$, Ikmalus Sholehah ${ }^{2}$ \\ Program Studi Tadris Biologi, Institut Agama Islam Negeri Kudus ${ }^{1,2}$ \\ iseulaelasari@stainkudus.ac.id ${ }^{1}$,ikmaiik0805@gmail.com²
}

\begin{abstract}
The study aims was to describe the relationship between students'creativity and cognitive learning outcome through the implementation of Project Based Learning (PjBL) on the biology of Fungi matter. Researchers use a correlational method of sampling as many as 25 students in $10^{\text {th }}$ grade being chosen by purposive sampling technique. The instruments used to collect creativity data are assessments of products referred to the creativity indicator as: (1) fluency, (2) flexibility and (3) novelty, while students' cognitive learning outcome data are 20 multiple-choice, 4 open-ended essay based on taxonomy Bloom's revision from $C 1$ to C6. Data analysis uses a statistic descriptive to know average and deviating standards of creativity and students' cognitive learning outcome, while to know the level of relationship between variables used non-parametric statistics through spearman's correlation test. The result shows that the average score of students' creativity in creating applied products relating to the function and role of fungi is 55.5 while the average results of students' cognitive learning outcome are 68.24. There is a middle correlation between creativity and students' cognitive learning outcome $(r=0.413)$.
\end{abstract}

Keywords: Creativity, Cognitive Learning Outcome. Project Based Learnig, Biology 


\begin{abstract}
ABSTRAK
Penelitian ini bertujuan untuk mengetahui hubungan antara kreativitas dengan hasil belajar kognitif siswa melalui implementasi Project Based learning (PjBL) dalam pebelajaran biologi materi Jamur. Peneliti menggunakan metode korelasional dengan sample sebanyak 25 siswa kelas $\mathrm{X}$ yang dipilih secara purposive. Instrumen yang digunakan untuk menghimpun data kreativitas berupa rubrik penilaian pembuatan produk yang mengacu pada indikator kreativitas berupa: (1) fluency, (2) flexibility dan (3) novelty, sedangkan data hasil belajar kognitif siswa dijaring dengan instrument test yang terdiri dari 20 soal multiple choice dan 4 open-ended essay yang didasarkan pada taksonomi Bloom revisi dari jenjang kognitif C1 sampai dengan C6. Analisis data menggunakan statistic deskriptif untuk mengetahu ratarata dan standar deviasi kreativitas dan hasil belajar kognitif siswa, sedangkan untuk mengetahui tingkat hubungan antara variabel digunakan statistik non-parametrik melalui uji korelasi spearman. Hasil penelitian mengungkap bahwa rata-rata nilai kreativitas siswa dalam membuat produk terapan yang berkaitan dengan fungsi dan peranan jamur adalah 55,5 sedangkan rata-rata hasil belajar kognitif siswa adalah 68,24 .Terdapat korelasi yang cukup kuat antara kreativitas dengan hasil belajar kognitif siswa dengan nilai korelasi sebesar 0,413.
\end{abstract}

Kata Kunci: Kreativitas, Hasil Belajar Kognitif, Project Based Learning, Biologi

\title{
INTRODUCTION
}

The learning process that refers to the scientific approach is a learning that takes scientific steps in acquiring knowledge. Knowledge obtained through that scientific step can be obtained through classroom learning or laboratory activity (Laelasari \& Supriatno, 2019). At the learning process with a scientific approach learners will be trained to observe, ask, gather information, experiment, analyze and can communicate learning or dare to express their opinions (Aruman, 2019). Learners are expected to be able to learn more self-reliant, more creative, and can think logically through learning with a scientific approach. The content of learning and the characteristics of learning materials is primarily science, when carefully peered closely at curriculum 2013. In the process of scientific learning with curriculum 2013, students are required to be actively involved in seeking and gathering information and can reconstruct their own knowledge, while the teacher as a facilitator and motivator. Natural science consist of four elements, namely science as a process, product, attitude and technology. Scientific activity aimed at framing natural phenomena so that the acquisition of scientific products is included in the scientific process (Sudarisman, 2015).

One of the branch of science that plays a large role in life is biology. If the field of science has four elements of process, product, attitude and technology, then those elements 
must also belong to biology. A student's biology is not sufficient when merely a body of matter or knowledge is involved. That means in the study of biology scientific activities or scientific processes are vital. Students should be actively involved in the learning process, starting from knowing the object, the symptoms and problems that are occurring, analyze, and being able to draw conclusions. Biological learning materials must also serve as tools or intermediaries to build the full knowledge, attitude, and skills of learners (Hw, 2012).

The new facts happening today are associated with changing learning patterns. The learning pattern initially carried out directly or face-to-face between educators and learners, but given that current conditions are still overcome by the covid-19 pandemic, the whole of good education at the elementary level of college carries out the online learning pattern (Laelasari \& Dewi, 2020). Online or otherwise known as online learning is a learning pattern that can contact students with learning resources whether teachers, databases, or libraries at different locations or long distances but can still interact by using information technology and communication (Abidin, 2020). Online learning patterns will be less significant without proper teaching methods or models. Since the effects of the covid-19 pandemic cannot be avoided, this process of learning is reduced to maximum because it cannot perform learning processes directly between teacher and student.

Project based learning is one of those learning models that refers to a scientific approach and can combine and support online learning patterns, making and shutting students into more autonomous work. Project based learning is one of those learning models that involves a project in the learning process. The first step of project-based learning is a problem presentation that can encourage learners to do identification to gather information and integrate new knowledge so as to receive the end result of the product (Widiasworo, 2018). It implies that students have a greater opportunity of learning and understanding the material and learning obtained will also increase.

Based on a preliminary study conducted through an interview with one of the biology teachers course gained a discovery that the study of fungi matter was done conventionally that was also combined with assignments, discussions, and practices. Biology study patterns are made via applications of Google classroom, Google meet, and whatsapp groups. In the online learning process researcher also find that learners are less active in responding to the 
learning materials. While the potential study of fungi matter to be raised as a project through study-based projects that end up producing a tangible product and could also enhance student creativity. Based on some of these theories and issues, one that researchers view as able to stimulate student's creativity in creating product and increasing student knowledge so as to get the results of meaningful cognitive learning is by using project based learning models. Application of project based learning models is expected to assist teachers in organizing online teaching learning activities, and directing students to develop creative ideas that motivate their creativity in making and producing real products, and training cognitive development.

\section{METHOD}

This research used a correlational method of sampling as many as 25 students in $10^{\text {th }}$ grade at MAN 1 Kudus being chosen by purposive sampling technique. The instruments used to collect creativity data are the product assessments that refer to the creativity indicator of (1) fluency, (2) flexibility and (3) Novelty (Silver, 2012). These assessments are used to measure students' creativity in planning and making applied products that deal with the function and role of fungi in life. As for the student's cognitive learning outcome data being linked with an optional test instrument of 20 multiple choice and 4 open-ended essays based on taxonomy bloom's revision ( $\mathrm{C} 1$ to $\mathrm{C} 6$ ). The validity and reliability of instruments have been measured both from construct validity and content validity. Instruments are given to students at the end of fungi material learning through the project based learning model $(\mathrm{PjBL})$. The resulting data on the score of creativity and cognitive learning outcome by the students were subsequently treated and tested with a statistic descriptive way to determine the average score of creativity and cognitive learning outcome and deviation standards. In the next step researchers tested normality data with Kolmogorov-Smirnov test, and the homogeneity data used the Levene test as a prerequisite test to determine which statistic test would be chosen. Based on the results of the next prerequisite test, Spearman's correlation was at a level of 0.05 with a SPSS version 16.0. for Windows. As for the category of correlation between variables based on Table 1 (Fraenkel \& Wallen, 2006). 
Tabel 1. Correlation Criteria

\begin{tabular}{cc}
\hline $\begin{array}{c}\text { Score of } \\
\text { Correlation }\end{array}$ & Correlation Category \\
\hline $0,00-0,20$ & very low \\
\hline $0,21-0,40$ & low \\
\hline $0,41-0,60$ & middle \\
\hline $0,61-0,80$ & high \\
\hline $0,81-1,00$ & very high \\
\hline
\end{tabular}

\section{RESULT AND DISCUSSION}

The statistic descriptive test of the student's creativity and cognitive learning outcome results is presented at the following Table 2 .

Table 2 Descriptive Analysis of Student's Creativity and Cognitive

\begin{tabular}{cccc}
\multicolumn{4}{c}{ Learning Outcome } \\
\hline Variable's score & $\mathrm{N}$ & Mean & $\begin{array}{c}\text { Deviation } \\
\text { Standard }\end{array}$ \\
\hline Creativity & 25 & 55,50 & 10,907 \\
\hline $\begin{array}{c}\text { Cognitive } \\
\text { Learning Outcome }\end{array}$ & 25 & 68,24 & 12,561 \\
\hline
\end{tabular}

Based on table 2 it may be known that implementation of project based learning models can train creativity and also affect students cognitive learning outcome on biology. It is supported by a similar study that claims that project based learning is viewed as an alternative to improving students' learning. Project based learning models are also good for use in biology because they have some of the attributes of learning that can create a conducive and nonmonotonous atmosphere of learning, and can inspire student creativity because teaching learning activities are based on contextual problems that are close to students' lives (Jagantara, Adinyana \& widiyanti, 2014). In the next step researchers take normality tests on the data of student creativity and cognitive learning. As for the results can be seen at Table 3.

Tabel 3. Normality Test of Creativity and Cognitive Learning Outcome

\begin{tabular}{cccc}
\hline Variable & \multicolumn{3}{c}{ Kolmogorov-Simirnov } \\
\cline { 2 - 4 } & Statistic & df & Sig. \\
\hline Creativity & 0,220 & 25 & 0,003 \\
\hline
\end{tabular}




\begin{tabular}{cccc}
$\begin{array}{c}\text { Cognitive Learning } \\
\text { Outcome }\end{array}$ & 0,085 & 25 & 0,200 \\
\hline
\end{tabular}

Based on Table 3 it may be known that the significance of creativity is 0.003 and the significance of cognitive learning results is 0.200 , while a failing value is 0.05 . A sig of creativity $0.003<0.05$, whereas cognitive learning value $0.200>0.05$. Thus, creativity data are not normally distributed while cognitive study data are normally distributed students. Continuity testing is done on both variables. As for the results of the homogeneity test being presented at Table 4.

Table 4. Homogeniety Test of Creativity and Cognitive Learning Outcome

\begin{tabular}{ccccc}
\hline \multirow{2}{*}{ Score } & \multicolumn{4}{c}{ Uji Levene's Test } \\
\cline { 2 - 5 } & Levene Statistic & df-1 & df-2 & Sig \\
\hline Creativity & 2,893 & 1 & 48 & 0,095 \\
\hline $\begin{array}{c}\text { Cognitive Learning } \\
\text { Outcome }\end{array}$ & 0,363 & 1 & 48 & 0,550 \\
\hline
\end{tabular}

Based on table 4 it can be known that the significance of creativity 0.095 and the significant value of cognitive learning outcome 0.550 , whereas the value excess is 0.05 . That is, $\operatorname{sig}(0.095$ and 0.550$)>\alpha(0.05)$. Thus the data of creativity and students cognitive learning outcome are homogeneous. Referring to the results of the normality and the homogeneity of the second variable data, spearman's correlation test was subsequently presented at Table 5.

Tabel 5. Correlation Between Creativity and Cognitive Learning Outcome

\begin{tabular}{lcc}
\hline Spearman's correlation & Creativity & $\begin{array}{c}\text { Cognitive Learning } \\
\text { Outcome }\end{array}$ \\
\hline Correlation coefficient $(\mathrm{r})$ & 1.000 & 0.413 \\
\hline Sig (2-tailed) & & 0.028 \\
\hline $\mathrm{N}$ & 25 & 25 \\
\hline
\end{tabular}

Based on Table 5 it may be known that the value of spearman's correlation for creativity and cognitive learning outcome is 0.413 , which means that the rate of the second variable is middle. Thus, if a student's creativity increases, then the results of cognitive learning outcome also increase. This result suitable with Habsari (2005) that suggests the creative intelligence supports high academic achievement. This agrees with research that reveals that there is a significant relationship between creativity and students' learning 
outcome (Maisari, 2012., Septiana, 2018., Botty, 2018., Banjarnahor, Winardi \& Dirgantoro, 2018., Nita, 2019).

The focus of learning is on using fungi in food processing. Students may select a menu of foods to be prepared. Through application of project based learning students are directed to perform and complete project assignments systematically by submitting to the syntax of project-based learning. The student independently (under teacher monitoring) determines the project's theme to be made, the project's completion ordinance, the working timeline of the project, carrying out the project assignment, and presenting the project (Klein, 2015). Students independently also search reference resources to gather data related to project assignments or project themes to be implemented to support the sustainability and sustainability of project projects given by teachers. So that students obtain more information not only from teachers but also information from sources or references that are relevant to the task at hand. The relevant data source is, in turn,supported data in discussion of the poduct report.

The results are supported by research that reveals that through the activities done in projectile-based learning can train students to develop skills such as organizing the projects and completion times, working with each student, conducting experiments related to assigned project assignments, searching for materials consistent with project assignments so that they can solve problems (Jagantara, Adinyana \& Widiyanti, 2014). The activity also makes it easier for students to mastery concepts . Agreeing with the principle of project-based learning presented by Klein (2015) as active learning, which can be exploited that growing information that leads to student questions and a desire for appropriate answers can create self-reliance in students. This should give students greater access to information and greater opportunities for mastering material.

Some research consistent with the results of this study suggests that project-based learning can increase students' creativity in making products because of the advantages of project-based learning among them; students actively participate in learning, teachers have opportunities to do inspiring services, facilitators, and motivators until students complete project assignments to produce a product, material mastery and creativity of students become increased, and train students to work together (Astuti, 2015). 
Creativity is a general ability to create new ideas that can be applied in problem solving, or asan ability to see an already existing element (Munandar, 2014). Creativity is also meaningful as the ability to create a new product. Not a whole product has to be new, perhaps new in the combination, but the elements have existed before (Komarudin, 2011). Student creativity can also be stimulated to more active both hand on and minds on through various learning activities based on active learning and also develop critical thinking skills such as inquiry or project based learning (Laelasari \& Hilmi Adisendjaja, 2018).

Project based learning is one of the innovative learning models whose learning is consistent with complex activities (Wena, 2010). Project based learning provides learners with opportunities in problem solving investigations, provides opportunities for students to work independently in deconstructing their own knowledge, and peak for real products (Fathurahman, 2015). Thus students can think, and study independently regarding the things that need to be done to complete the project and produce the product.

According to research data acquired by researchers, student creativity is reflected in products made by the student. The product produced by the student is processed food by using the mold in the process of making or processing it and then featured in the product report. The products that students make and produce vary both in terms of the type of products, how products are made, and how they are packaging. This is similar to some previous studies that project based learning effectively enhances student science and creativity skills (Kusumaningrum \& Djukri, 2011). One of the principles of project based learning is that it enhances and develops students' skills in locating a resource or tool for task completion. So student participants truly have a dominant role in determining, designing, and carrying out project assignments to produce real products (Fathurrohman, 2015). Projectbased learning contributes to students' learning in accordance with the concept of project based learning that gives students the opportunity to collect information on materials or discussion topics, and experiment in groups. So that learning is more meaningful and picking up with all the students is finally able to answer the guiding questions.

Similar studies, which call the model project based learning is one way of improving students' learning. Students being able to understand a teach material is not enough if remembering, but students must be able to implement the material in an existing problem. 
Students who already have concept understanding are more likely to implement and resolve a problem. Immediate experience is capable of forming a concept either through meaningful words or pictures and all of it is in project-based learning (Insyasiska, Zubaidah \& Susilo, 2015).

\section{CONCLUSION}

There is a middle correlation between creativity and students' cognitive learning outcome through the implementation of project based learning model with 0.413 correlation coefficient. This suggests that if a student's creativity increases then the results of a student's cognitive learning outcome also increase. The implementation of project based learning is viewed can inspire students' creativity in creating food-processed products by using fungi on average of 55.50 and developing cognitive learning outcome by average of 68.24.

\section{REFERENCE}

Aruman. (2019). Implementasi Kurikulum 2013 dalam Manajemen Pembelajaran Peminatan IPA. Jurnal Manajemen Pendidikan: (13) 20-21.

Abidin, Z. (2020). Pembelajaran Online Berbasis Proyek Salah Satu Solusi Kegiatan Belajar Mengajar di Tengah Pandemi Covid-19. Jurnal Ilmiah Profesi Pendidikan: (1) 65.

Astuti, R. (2015). Meningkatkan Kreativitas Siswa Dalam Pengolahan Limbah menjadi Trash Fashion Melalui PJBL. Jurnal Bioedukasi 2015: (8) 39.

Banjarnahor, E., Winardi, Y., \& Dirgantoro,K. P.S. (2018). Hubungan Antara Kreativitas Dengan Hasil Belajar Kognitif Siswa Kelas X IPA Basic SMA ABC Pada Pembelajaran Matematika. Journal of Holistic Matematic Education: 2 (1), 34-44.

Botty, M. (2018). Hubungan Kreativitas Dengan Hasil Belajar Kelas V Mata Pelajaran Bahasa Indonesia Di MI Ma'had Islamy Palembang. Jurnal Ilmiah PGMI: 4 (1), 41 55.

Fathurrohman, M. (2015). Model-model Pembelajaran Inovatif. Yogyakarta: Ar-Ruzz Media.

Fraenkel \& Wallen. (2006). Pendidikan-Metodologi Penelitian. New York: McGraw Hill.

Hw, P. (2012). Biologi Sains Lingkungan dan Pembelajarannya dalam Upaya Peningkatan Kemampuan dan Karakter Siswa. Seminar Nasional IX Pendidikan Biologi 2012. Surakarta: FKIP UNS. 
Habsari, S. (2005). Bimbingan dan Konseling SMA. Jakarta: Grasindo.

Insyasiska, D., Zubaidah, S.,\& Susilo, H. (2015). Pengaruh Project Based Learning terhadap Motivasi Belajar, Kreativitas, Kemampuan Berpikir Kritis, dan Kemampuan Kognitif Siswa pada Pembelajaran Biologi. Jurnal Pendidikan Biologi: (07) 19.

Jagantara, I.M.W, Adinyana, P.B \& Widiyanti, N.L. (2014). Pengaruh Model Pembelajaran Berbasis Proyek (Project Based Learning) di terhadap Hasil Belajar Biologi Ditinjau dari Gaya Belajar Siswa Biologi SMA. e-Journal Program Pascasarjana Universitas Pendidikan Ganesha Program Studi IPA (4).

Klein, Joel I. Project-Based Learning: Inspiring Middle School Students to Engage in Deep an Active Learning. NYC: Department of Education.

Komarudin, Dindin. (2011). Hubungan antara Kreativitas dengan Prestasi Belajar Siswa. Psympathic Jurnal Ilmiah Psikologi 2011: (4) 279.

Kusumaningrum, Sih \& Djukri, D. (2016). Pengembangan Perangkat Pembelajaran Model Project Based Learning (PjBL) untuk Meningkatkan Keterampilan Proses Sains dan Kreativitas. Jurnal Inovasi Pendidikan IPA 2016: (2) 241.

Laelasari, I., \& Dewi, N. P. (2020). Penerapan Pembelajaran Daring Berbasis Whatsapp Group Untuk Siswa Madrasah Ibtidaiyyah di Tengah Pandemi Covid-19. Jurnal Penelitian, 14(2), 249. https://doi.org/10.21043/jp.v14i2.8447

Laelasari, I., \& Hilmi Adisendjaja, Y. (2018). Mengeksplorasi Kemampuan Berpikir Kritis Dan Rasa Ingin Tahu Siswa Melalui Kegiatan Laboratorium Inquiry Sederhana (Vol. 01). Retrieved from http://journal.stainkudus.ac.id/index.php/Thabiea

Laelasari, I., \& Supriatno, B. (2019). Analisis komponen penyusun desain kegiatan laboratorium bioteknologi. JURNAL BIOEDUKATIKA, 6(2), 84. https://doi.org/10.26555/bioedukatika.v6i2.10592

Maisari, A. (2012). Hubungan kreativitas Dengan Hasil Belajar Siswa Dalam Mata Pelajaran Penataan Sanggul Pada Siswa Kelas XI SMK N 7 Padang. Skripsi: Universitas Negeri Padang.

Munandar, U. (2014). Pengembangan Kreativitas Anak Berbakat. Jakarta: PT Rineka Cipta.

Nita, O. (2019). Hubungan Kreativitas Dengan Hasil Belajar Bahasa Indonesia. Jurnal KIBASP: 3 (1) 92-103.

Septiana, R., Gani, R.A., \& Elizabeth, Y. (2018). Hubungan Kreativitas Belajar Siswa Dengan Hasil Belajar Ilmu Pengetahuan Alam. Proceedings: 1 (1). 
Sudarisman,S. (2015). Memahami Hakikat dan Karakteristik Pembelajaran Biologi dalam Upaya Menjawab Tantangan Abad 21 serta Optimalisasi Implementasi Kurikulum 2013. Jurnal Florea: (2) 31.

Wena, M. (2010). Strategi Pembelajaran Inovatif Kontemporer: Suatu Tujuan Konseptual Operasional. Jakarta: Bumi Aksara.

Widiasworo, Erwin. (2018). Strategi Pembelajaran Edutainment Berbasis Karakter. Yogyakarta: Ar-Ruzz Media. 